\title{
Method of Teaching Arabic in Madrasah Tarbiyah Islamiyah Koto Panjang Lampasi Payakumbuh
}

\author{
Received: $05^{\text {th }}$ April2016; Revised: $06^{\text {th }}$ April2016; Accepted: $19^{\text {th }}$ July 2016 \\ Permalink/DOI: http://dx.doi.org/10.15548/it.v23i3.247
}

\section{Syar'i Sumin}

Universitas Andalas Padang, West Sumatra, Indonesia

Email: srsumin@gmail.com

\begin{abstract}
Methods of teaching Arabic and their innovations will be a challenge for any teachers of Arabic. Therefore, teaching Arabic will also require the intelligence of each teacher to understand the aspects related to learning outcomes, namely by creating new techniques in teaching Arabic language so that students become more active, skillful, able to master and proficient Arabic. Boarding school of Madrasah Islamiah Tarbiyah Koto Panjang Lampasi has proven itself as the school of giving motivation, and innovation in the development of generations of people who have been able to reach the highest point of improvement, both in quantity and in quality of the students' achievements. The method used in this research is qualitative descriptive which describes methods of teaching Arabic at MTI Koto Panjang Lampasi Payakumbuh. The source of the data of this research is the teachers, students, the foundations, and community. The technique of collecting data obtained from various teachers who taught Arabic at MTI through interviews and observations. The results showed that there are 10 steps of Arabic language learning method applied in MTI Koto Panjang.
\end{abstract}

Keywords: Teaching method, Arabic, learning method, systematic teaching

How to Cite: Sumin, S. (2016). Method of teaching Arabic in Madrasah Tarbiyah Islamiyah Koto Panjang Lampasi Payakumbuh. Al-Ta Lim Journal, 23(3). doi: http://dx.doi.org/10.15548/jt.v23i3.247

\section{INTRODUCTION}

Arabic is a language that has touched different spheres of the world. Apart from being a media language teaching of Islam, the Arabic language has also been instrumental in upholding science rapidly. Arabic is a language that is not foreign among Muslims, especially the students who live in boarding schools, both public and private. Related to the importance of this issue, technology will be enriching national treasures of the culture and changing of political international media which increasingly manifest the role of Arabic now. As a result, this language has developed very beside Arabic as a language of instruction to examine the deeper value of Islamic treasures that have been passed by the Prophet and the Companions and scholars in the past, teaching Arabic and its innovation will be a challenge for any teacher of Arabic. Therefore, learning Arabic will also require the intelligence of each teacher to understand the aspects related to learning outcomes, namely by creating new techniques in teaching the Arabic language so that students 
become more active, skillful, able to master and proficient in Arabic.

According to Syahin, (2006), the Arabic language education today faces a number of serious challenges. First, due to globalization, the use of Arabic fushha among Arab societies begins to decrease the frequency and proportion. It tends to be replaced by the Arabic 'amiyyah or local dialect (al-lahajat al-mahalliyyah). Second, the reality of Arabic language is now also faced with the challenge of globalization, specifically the lifestyle and the colonization of the West. Third, the tide of the silting of morals, faith, and the distancing the youth of Islam is from the sources of Islamic principles through a bad image of Arabic language.

Beside there is an attempt to replace Arabic alphabet with the Latin ones, Arabic in the educational institutions in the Islamic world also began to be shifted although it is not replaced by either English or French as the language of instruction in science lessons. In addition, Arabic language studies in educational institutions are also experiencing disorientation: no clear direction and purpose. This is reflected in the structure of curriculum program of PBA which some subjects do not apparently relate to the vision and mission of PBA. Then, the policy of teaching Arabic in Islamic schools and other educational institutions is also unclear.

As it is known that the boarding school is educational institutions, social, religion, and community which can be considered as the scaffolding of the development, particularly in the development of mental and religiousness. Also, Boarding school can be social activities that constantly monitor the situation and development of the society to be free from all oppression, moral decadence and poverty in science. In other words, boarding school is a place of transformation values in relation amar ma'ruf nahi mungkar. The distinctive character of boarding school makes it difficult to seek the origin of boarding school. Islamic tradition could not be generalized, considering almost all the schools have their own characteristics that come from their history respectively.

In relation to the meaning of Boarding schools as an educational institution of social, religious or Islamic center, boarding school of Madrasah Islamiah Tarbiyah Koto Panjang Lampasi is playing an important in proving itself as a motivator and innovator in the development of young generations. When viewed the developments of MTI during the life of Sheikh H Muchtar Ongku Lokuang as the founder of MTI Koto Panjang Lampasi, MTI has been able to reach the highest point of progression, for quantity of the students and for quality of the students' achievements, teachers who teach relate to his own' fields, the strict management and the stability of funds that is harmonious relationship of all parties. The key of the success and the stability of all aspects of the subject are determined by the work ethic and sincerity.

The role of the figure of a person in society and in maintaining the existence and survival of an educational institution, the growth, the development and experiencing the results of the progress are really significant in advancing the nation, the state, and religion. It is strongly felt and proved in a school called Madrasah Tarbiyah Islamiyah (MTI) Koto Panjang Lampasi Payakumbuh.

Indeed, quite a lot of Islamic educational institution grows and develops in Payakumbuh. This indicates that the predecessors and community leaders aware of the importance of religion education itself. Especially for society in Koto Panjang Lampasi, MTI Koto Panjang is institution that gives Contributions and extra value in the effort to educate the nation's children. Of course, the number of students who have graduated from the bench MTI Koto Panjang Payakumbuh Lampasi is quite a lot too, and average of students who had studied in Koto 
Panjang Lampasi MTI is not only the students coming from Payakumbuh and Kab. 50 City but also coming from other regions, such as Riau, Jambi, Bengkulu, South Sumatra, North Sumatra, Aceh, and others. The interesting learning method in delivering the lesson to students and worshipers is a comprehensive method. It was known as the ten steps learning methodology.

However, whether a method is effective or not, it depends on the person who applied in the field Jensen (2009) It does require sincerity, physically and spiritually healthy, comprehending the material thoroughly, understand the conditions and capability of the students, well-prepared material and consistently implemented, continuity, and high motivation. Teachers play an important role, even the teacher becomes an dominant factor in the success of teaching in the classroom Abdullah (2002), Lee (2004). Teachers may be viewed from three angles: first; proficiency of teachers in teaching, second; proficiency of teachers in the master the subtleties of the materials being taught and third; the teacher's personality Abdullah (2002), Brophy (1986), Cajkler \& Addelman (2013), Krashen \& Terrell (1983), Paris (2004), Rhee \& Pintrich (2004), Roberts, Roberts (1991).

\section{METHOD}

The method used in this research is qualitative descriptive which describes methods of teaching Arabic at MTI Koto Panjang Lampasi Payakumbuh. Data was taken from the teachers, students, the foundations, and community. The technique of collecting data obtained from various teachers who taught Arabic at MTI through interviews and observations. The data obtained had been verified by triangulation from the various aspects that have been verified according to the Arabic language teaching techniques applied by buya Sheikh H. Muchtar Ongku Lokuang.

\section{RESULT AND DISCUSSION}

Not much different from Educational religions Institutions in Payakumbuh, who grew up in the Dutch colonial era, MTI Koto Panjang believes that the educational success of a student is supported by three factors, namely: schools, parents and the environment Masidjo (1995). These three elements come along together and support each other; undoubtedly a success will be achieved. Based on the information obtained from various the teachers who taught at MTI the school always gives a kind of conscious awareness to his students about the three essential aspects that will support each other. Related to that purposes, also, in every meeting with the students' parents, the school also reminds the role of the parents in their children's success.

While in the community, the school always asks the society to jointly care of the education of the children. In relation to this, the community actively participates to support the entire work program of the school. In these conditions, it seems the school has carried out a kind of "a sense of belonging and a sense of responsibility "that embraces parents and the community to achieve the school's progress. No wonder if various programs received real support from the parents and the community (Environment). This has become the backbone and motivation of schools to carry out various physical development activities. At first, the building school was originally simple and very unpretentious, but because of the support of parents and the community, the condition of the building of progressively increases

When specifically viewed, the teaching learning programs implemented in Madrasah Tarbiyah Islamiah (MTI) Koto Panjang is quite different compared to other educational institutions. Madrasah Tarbiyah Islamiah (MTI) Koto Panjang applied 7 years educational term, which Tsanawiyah (junior high school level) spends for 4 years and Aliyah (senior high school level) for 3 
years. The curriculum implemented focuses on oriented subjects (the subject matter of curriculum), to the needs of the students (child center curriculum) and the needs of real life (life skill curriculum). The more specific curriculum of Madrasah Tarbiyah Islamiyah is the deeper comprehension on "Kitab Kuning", so that students who graduate from this school are able to read the book (Kitab) which are not lined. By mastering the school lesson, students are expected to become preachers and prospective prominent religious scholars in the community.

In giving lessons, before continuing the lessons, the methods of learning Arabic in MTI's Koto Panjang are first rechecking the students' understanding on the lessons already taught previously. Teachers ask one by one, every student is asked. For example, the teacher read words in Indonesian, and the students were told to translate them. An Arabic word has several derivations (Tasrif). When an Arabic word was translated, it should be known the contain structure of of the word. If the structure is unknown by the translator, it will cause wrong translation. Teachers told a student to translate the words, if he or she got wrong translation; the translation would be forwarded to students at his/her side. Although the word can correctly be answered for one of many words that the teacher asked, but the feeling of happiness appears. By this way, students felt lesson was alive, and reawaken the spirit of revision at night and the following days.

When teaching istdlal, the students also got a new science at the same time, because only Syekh H. Muchtar Ongku Lokuang wrote it. He also teaches them a lesson directly to the students. None of the teachers ever teach that subject. The way he teaches is very sympathetic, relaxing but firm and pleasant. The curiosity of being asked by Syekh H. Muchtar Ongku Lokuang pushes the students to read the lesson previously although finally they were not is able to answer it.
Based on the findings, the Arabic language learning methods applied in MTI Koto Panjang are:
a. طريقة قواعد اللغة العربية (Thariqah qawa'id al-lughah al-Arabiyah)
b. طريقة التمهيد بالسئو ال (Thariqah al-Tamhid bi al-Sual)
c. طريقة التقرير بالمراجعة (Thariqah al-Taqrir bi al-Muraja'ah)
d. طريقة الثرح بالمثنال (Thariqah bi al-Sharh al-mithal)
e. طريقة المثال (Thariqah al-mithal bi al- Naql)
f. طريقة التعريف بالفهم (Thariqah al-Ta'rif bi al-Fahm)
g. طريقة الإتقان بالثوا اهد (Thariqah al-Itqan bi al-Syawahid)
h. طريقة التعليم بالمر اقبة (Thariqah al-Ta'lim bi al-Muraqabah)
i. طريقة الحث والمحاسبة للطلاب (Thariqah al- Hatsts wa al-Muhasabah Li al-Thullab)
j. طريقة بناء الأمة بالدعوة (Thariqah binai bi al-Ummah al-Da'wah)

Each teaching staff, mainly, the educator, certainly has a particular way, strategy and method in transferring his thoughts and presenting the lesson material. The success of the students to understand a lesson is defined by the method implemented by the teaching staff. One of the teaching and learning model which is now developed is a model of Active, Creative, Effective and Ejoyable (PAKEM) (Ainak, 2009). Buya Sheikh H. Muchtar Ongku Lokuang preserved the method that he always practices with a characteristic way of his students. Some student had Similar understanding and conclusion with him regarding to the method of teaching, and some other had various Conclusions in understanding and conclusions of the methods applied by Buya in educating their students. The following are to be Introduced one by one in brief:
a. العربية (Thariqah qawa'id al-lughah al-Arabiyah).

Scholars and practitioners learning foreign languages often call this 
method as the traditional method. This relates to a reflection on the ways in Ancient Greece and Latin in teaching language. The basic assumption of this method is the universal logic which is the basis of all languages in the world, while the grammar is a branch of logic. Qawa'id is a description of the rules that apply in every language. Moreover, qawa'id is a subsystem contained in the language in which one unit combine to form larger meaningful units. Hockett (1958) provides another definition that grammar or qawa'id has the system of rules or patterns that apply to a language. The rules of a language are obtained on the basis of researcher's analysis on the same patterns used repeatedly. (Brown, 1994) argues that grammar or qawa'id is a system of rules that affect the structure and relationship of words conventionally in a sentence. This understanding implicitly states that there are elements forming the sentence that become a study in grammar, morphology and syntax.

Thariqah qawa'id al-lughah alArabiyah is a method of emphasis and Priority of Arab Language Elementary items, namely mastery on linguistics such as morpho-syntax (Nahwu, Sharf), Rhetoric (Balagha) and Usul al-Fiqh, Including Qawa' id fiqhiyah, qawa'id Ushuliyah and Manthiq Whose implementation is seen in the subject of "Al-Istidlal" given to the students at class V, VI and VII. Those are the knowledge that Buya Syekh H. Muchtar Ongku Lokuang always emphasized to his students. Besides, he also mastered Syariah/ Fiqh Al-Quran / interpretation (Tafsir) and the Hadits as well as Tasawuf and Thariqat.

According to Aisyah (2013) sharf is science that addresses the basics of word formation, including augmentation. Meanwhile, the meaning of a sentence in Arabic grammar is the science which deals with the state of the word in its formation into a sentence. Sentence formation in Arabic is studied in nahw (syntax) (Fahrurrozi \& others, 2009). This method is intended to the learners in order to, (1) more able to read the manuscript in Arabic or Arabic literature, and (2) has a value of discipline and intellectual development. Learning in this method is dominated by reading and writing. The vocabulary learned is the vocabulary in reading test, in which the sentence is assumed to be the smallest unit in the language, translation accuracy precedence, and the mother language is used in the process of learning.

The examples of using al-qawaid method in learning Arabic language can be carried out as follows:

1. Repeating mufradat materials. Students note the new mufradat when the teacher read the original language translation (Arabic)

2. The teacher asked some students read the passage in the book aloud. After that, the teacher reads a few sentences and then provides opportunity for students to repeat reading silently.

3. The students translate reading texts into target language. Teacher helps the students who face difficulty if needed

4. Then, start the main lesson with an explanation about nahwu (grammar). The rules are explained in detail in the source language (Arabic). The students note the rules with explanation

5. At the end of the lesson, students spent time working on written assignments that are related to nahwu from Arabic to target language. Then, it is given the task of memorizing new mufradat relating to the next lesson. (Riska, 2014) 
b. طريقة التمهيد بالسئوال (Thariqah al-Tamhid bi al-Sual)

Thariqah al-Tamhid bi al-Sual is method of brainstorming question. Brainstorming method question is a form of discussion in order to collect ideas, opinions, information, knowledge, experience, of all participants, Fathurrohman \& Sutikno (2007). In contrast to the discussion in which the idea of a person can be addressed (supported, furnished, reduced, or not approved) by the other participants, in Brainstorming methods opinions of others are not going to be responded. This method is based on the idea that a group of people can propose more ideas from its individual members. In this method, it was presented a problem. Then the participants were invited to propose any ideas on the subject, questions in this method are designed to help the group to identify key issues to be solved.

Thariqah al-Tamhid bi al-Sualis a method of brainstorming question, comprehending and thinking in internalizing the previous lesson. $\mathrm{He}$ used this method to add and give the materials, generally he wrote an Arabic word then he asked his students who could read this word at least in 19 forms such as with nine readings. All students were asked about the 9 readings. Buya commented to students who could answer "Iko nan lai mangaji ruponyo" (they understand and they are active and smart). While those who could not answer it, then Buya said: "Lubuaknyo indak ba ikan" (the lesson is not understood yet). However, Buya is always optimistic, there was a student who could answer it and there was a student who couldn't. Everything is taken to be learned for future development. c. طريقة التقرير بالمر اجعة (Thariqah al-Taqrir bi al-Muraja'ah)

Taqrir words have multiple meanings and understanding: تقرير means the statutes / reality and - يقرير means living/ quite. Al-Jarjani distinguishes between Taqrir and Tahrir. Tahrir explains what kinayah is while Taqrir provides an explanation of understanding implicitly. While in terms of nahwu, meaning always remains coincide with continuity (Dawam wa istimrar), so this sense in education is closer to continuity in learning in order to achieve maximum results.

Muraja'ah is repeating memory already played to teachers or kyai. Memory which has been played or presented to teachers or kyai was originally memorized well and smoothly, but sometimes it is still forgotten even lost altogether. Therefore, it is necessary to do Muraja'ah or repeat the memory which has presented to teachers or kyai.

There are three ways of reproducing texts: First, the overall repetition (Tikrarul Jam "iy). Repetition in this way involves all students in a class. This way is done before the other ways. This method is very useful for togetherness in the classroom and is also useful for learners who feel embarrassed if repeating by himself. In addition, it also can encourage the majority of learners to try to pronounce a word or phrase together before he pronounces them alone. Second, repetition is for every group (Tikrarul fiawiy). Repetition is done by dividing the class into groups. Repetition is done by each of the groups. This way is a middle way between the entire way and personal way. Its function is to limit students involved in repetition so that the teachers can monitor their repetition and know their mistakes. Third, Personal repetition (Tikrarul Fardiy) is carried out 
by each learner at any time. Once a learner completed, he is followed by a second, third, and all or most learners do. This type is the most important and beneficial because it is closer to the natural way to pronounce. We know that a person speaks in his own; not together. Personal repetition also strength then the teacher to follow what the learners say and correct them when necessary. But this kind of repetition has a weakness. it can be time consuming. So, sometimes it is insufficient especially when the number of learners is big enough. Therefore, in choosing the type of repetition, teachers need to consider the available time and the number of learners in one class.

Thariqah al-Taqrir bi alMuraja'ah is a method of internalizing by repeating the lesson in order to master them. It is started from the lessons which have already been discussed and came along with the new ones. By doing this, the students who are active and lazy could be identified. This method was little bit frightening for the students since some of them were shy to review the lessons in front of their friends and they were afraid of Buya for the unanswerable questions. This would increase the students 'awareness to be careful and active, so that all the materials were actually mastered holistically and integrally.

d. طريقة

(Thariqah bi al-Sharh al-mithal).

The word mithal is from word mim, sin, and lam, which has comparative meaning between something to something else. Etymologically the word of mithal is the plural form of the word mass and example. Parable, something resembles and comparison. While in the terminology, mithal is an expression which is told and has been popular with the intent of likening the circumstances contained in the words of the state something for which words are spoken (Chirzin, 1998).

According Muchtar (2005) in his book "Fikih Education", mitsal method is giving the example from the abstract to theconcrete to achieve the goal or take advantage of the parable. Usually parable is mentioned to explain the principles or concepts (English, n.d.). According to Ibn Qayyim Jauziah, adapted by Fuad bin Abdul Aziz AlSyalhub, in his book, "Quantum Teaching", the parable is an analogy and the like that are useful as an illustration and explanation. (Al-Syalhub \& Abdul, 2005) Based on some definition about mitsal presented, it can be concluded that, mitsal is a teaching method where teachers deliver learning material through example or metaphor for obtaining a description or explanation concretely about the material presented, so it is easy to be understood.

Thariqah bi al-Sharh al-mitsal is the method of equivalence between the definition and example. Every time adding new subject matter, Buya always starts by giving various examples in accordance with the details of discussion about the material, rather than inserting another material. Buya means by this method, he gives a complete understanding and comprehension to the students, so the students do not just memorize the definitions without knowing the example. Definitions, examples and understanding is like tali tigo sapilin dan tungku tigo sajarangan, it means so strongly linked holistically and integrative.

Therefore, an educator has responsibility to improve the quality of education. One good method used in addition to other methods is amtsal method or parable. With these methods can indirectly enable cognitive, affective 
and psychomotor of learners. So, it can be applied in everyday life, both within the family, school, and community circles. The success of education highly depends on how our methods enable the cognitive, affective and psychomotor.

\section{e. طريقة المثال بالنقل (Thariqah al-mithal bi al-Naql)}

This is an example methodwith proposition of Naql (by giving examples from Qur'an and Hadith). Each Buya should give examples that taken from Qur'an or Hadits. He was not interested in example like زيد قائم (example mubtada / Subject and Khabar / predicate), but he was delighted if the example is such محمد رسول الش . Buya was less sympathetic if the example was such إن زيدا قائر but buya was very happy if the example was إن الدين عنداله الاسلام (in relation isim and khabar ). Through this method, buya intends that many students read and discuss al-Qur'an as the early pondation to memorize alQur'an (Muqoffi \& others, 2013).

\section{f. طريقة التعريف بالفهم (Thariqah al-Ta'rif bi al-Fahm)}

This is a method of giving understanding/ definition after comprehension. Once students understand the issues addressed through examples, then Buya Sheikh H. Muchtar Ongku Lokuang provides a definition of the problems being studied. It is possible that there could have been a various definitions of a thing, as long as the purpose is the same. So, the students were able to express an issue that is being discussed. If students are able to define something, they must be good also in giving examples. That is the Buya's way in fostering his students. It becomes one of his characteristics that need to be continued and disseminated by the future generations. g. طريقة الإتقان بالثو اهد (Thariqah al-Itqan bi al-Syawahid).

This method used to understand and validates the truth through standard rules that have been popular. This method is intended to open up and to give back the control of the concept of the sciences he had learned before; such as mubtada 'and khabar ( ) with all of the terms and descriptions. So Buya in this case, asks the students to read the poems from the book "Matan Alfiyah" or other matan matan-that explains about the definition and all conditions relating to the study. Through this method, he intends that the students can master the knowledge theoretically and practically and continuously. (Rao \& Rashid, 1983).

h. طريقة التعليم بالمر اقبة (Thariqah al-Ta'lim bi al-Muraqabah)

This method is monitoring and observing the Teaching and Learning used in the classroom. In order to educate students and strengthen the teachers skills in delivering course material and consolidating the expertise of a teacher. Therefore, this method becomes one of the priority programs in improving human resource such as students and teachers.

In this case, Buya often observes, supervises, peeps the teacher's teaching. Sometimes he evens do a kind of undercover role for example he presently peeked out from behind the wall (as if he was cleaning a dirty place); he is very seriously observe and listen to the teachers who are teaching in order he can see the effectiveness, efficiency and capability of the teacher. Then, as the feedback, he wisely meets and discuss with the teachers at other times so the teacher can get feedback directly from him. Finally, the teacher feels satisfied and happy to meet and obtain advice from him. Syahruddin, Herawaty, \& Ningrat, 2013) such guidance, friendship 
and cooperation that he worked up in her lifetime makes the quality of education in Madrasah Tarbiyah Islamiyah (MTI) become developed greatly. This becomes the pride of the school because the quality of students is determined primarily by the quality of their teachers.

i. طريقة الحث و المحاسبة للطلاب (Thariqah alHatsts wa al-Muhasabah Li al-Thullab)

The methods provide motivation and evaluation of to the students. He directs the learners with the encouragement of ideals and hope, optimism, improvement of the quality of science, worship and morals of the learners. Then, it also improves the reputation of Madrasah and for students who have graduated and go to college. He always monitors the progress of his students who have studied at a high level of education as university and always provide encouragement, and pray, so the learner really gets blessing in the science. The atmosphere also becomes more positive, both for students who are still at MTI and the others in Higher Education. He is very appreciative and proud of the achievements of the students and he deliberately sought information of the students 'achievements when they were in the College. He looked for the achievements as the highest grade at a university or students who were outstanding in their field, such as qiraat Qur'an, Arabic Language, Speech, and etc.

j. طريقة بناء الأمة بالاعوة (Thariqah binai bi al-Ummah al-Da'wah)

The methods invite People to share the concept of Islam and to foster Islamic community meeting through $w a$ al-Hikmah al-Hasanah Mau'izhah Jadilhum wa bi al-Lati hiya Ahsan. He actively proselytizes for the people, both in campus and out campus. He set up and share Islam value (weekly Islam meeting), both for the public or for particular members, namely fostering mosque discussion group. This group aims to deepen knowledge, sharpen the mind and understanding and confidence and tenacity in using the argument in explaining verses. Through this the agency of assemblies, he develops, builds community and socializes Madrasah Tarbiyah Islamiyah (MTI) while retaining the characteristic of Madrasah among Muslim intellectuals, so Madrasah Tarbiyah Islamiyah (MTI) Koto Panjang find glory in the era of Sheikh H. Muchtar Ongku Lokuang, so that through the achievement of the alumni, the proselytizing and informal gatherings, he promotes MTI to the whole archipelago and even to the neighbor countries.

\section{CONCLUSION AND RECOMMENDATION}

The methods are adopted and developed by Buya Sheikh H. Muchtar Ongku Lokuang at MTI Koto Panjang. These methods can be a role model for the lesson for the next generations in particular and Muslims in general.

It is suggested that using the appropriate methods is essential in the teaching and learning process of Arabic. It has been proven in the study conducted in Madrasah Tarbiyah Islamiyah (MTI) Koto Panjang.

It is also recommended that the evaluation on the implementation of any teaching methods for Arabic is an important task of every teacher. It is their duty that needs to be done continuously and cannot be handed over or neglected that the teaching method can succeed in improving Arabic learners' ability.

\section{REFERENCES}

'Abd, S. S. (2006). Al-Tahaddiyat al-lati tuwajihu al-lugha al-'Arabiyyah. Rabath: Isesco. 
Abdullah, T. (2002). Ensiklopedi tematis dunia Islam/ketua dewan editor. Taufik Abdullah. Retrieved from http://repository.tufs.ac.jp/handle/101 $08 / 443$

Ainak, R. (2009). Implementasi Pembelajaran Bahasa Arab Model Pembelejaran Aktif, Kreatif, Efektif, dan Menyenangkan (PAKEM) di Madrasah Ibtidaiyah Sunan Pandanaran Ngaglik Sleman Yogyakarta. Retrieved from http://digilib.uin-suka.ac.id/3271/

Aisyah, D. (2013). Analisis teknik pengajaran qawa'id. Jurnal Ilmu Pendidikan, 16(1).

Al-Syalhub, A. A. B. F., \& Abdul, A. (2005). Panduan praktis bagi pendidik quantum teaching. 38 langkah belajar mengajar EQ cara Nabi SAW. Jakarta: Zikrul Media Intelektual, Terjemahan Abu Haekal.

Brophy, J. (1986). Where are the data?: A reply to confrey. Journal for Research in Mathematics Education, 17(5), 361-368.

Brown, H. D. (1994). Teaching by principles: Interactive language teaching methodology. NY: PrenticeHall Regents.

Cajkler, W., \& Addelman, R. (2013). The practice of foreign language teaching. Routledge.

Chirzin, H. (1998). Ilmu dan agama dalam pesantren. Jakarta: Kalam Mulia

English, C. (n.d.). How and why the teaching framework was developed. Retrieved from

http://www.cambridgeenglish.org/ima ges/165885-teaching-frameworkresearch.pdf

Fahrurrozi, A., \& others. (2009). Penerapan pembelajaran kooperatif metode group investigation untuk meningkatkan pemahaman siswa terhadap konsep redoks. Retrieved from

http://repository.uinjkt.ac.id/dspace/h andle/123456789/15821

Fathurrohman, P., \& Sutikno, M. S. (2007). Strategi belajar mengajar: strategi mewujudkan pembelajaran bermakna melalui penanamn konsep umum dan konsep Islami. Refika Aditama.

Hockett, C. F. (1958). A course in modern linguistics. Language Learning, 8(34), 73-75.

Jensen, E. (2009). Different brains, different learners: How to reach the hard to reach. Corwin Press.

Krashen, S., \& Terrell, T. (1983). The natural approach. Hayward. CA: Alemany Press.

Lee, I. (2004). Error correction in L2 secondary writing classrooms: The case of Hong Kong. Journal of Second Language Writing, 13(4), 285-312.

Masidjo, I. (1995). Penilaian pencapaian hasil belajar siswa di sekolah. Walter de Gruyter.

Muchtar, H. J. (2005). Fikih pendidikan. Bandung: PT. Remaja Rosdakarya.

Muqoffi, S., \& others. (2013). Analisis buku teks " ta'lim al-lughah al-" arabiyyah pendidikan Bahasa Arab SMP/MTS Muhammadiyah kelas VII" karya Muhammad Thariq Aziz, S. Pd. I dan Nurul Cholidiyah SHI (tinjauan dari segi materi)." UIN Sunan Kalijaga. Retrieved from http://digilib.uinsuka.ac.id/7743/

Paris, R. (2004). At war's end: building peace after civil conflict. Cambridge University Press.

Rao, B. V. N., \& Rashid, M. S. (1983). Direct observations of deformation- 


$$
\begin{aligned}
& \text { induced retained austenite } \\
& \text { transformation in a vanadlum- } \\
& \text { containing dual-phase steel. } \\
& \text { Metallography, 16(1), 19-37. }
\end{aligned}
$$

Rhee, C. R., \& Pintrich, P. R. (2004). Teaching to facilitate self-regulated learning. Thinking about Thinking. What Educators Need to Know, 3147.

Riska, P. D. (2014). Peningkatan hasil belajar bahasa arab melalui metode al-qawaidwa-tarjamah menggunakan media visual gambar bagi siswa kelas
IV MIN Kolomayan Wonodadi Blitar tahun ajaran 2013-2014. Retrieved from http://repo.iaintulungagung.ac.id/281/

Roberts, E. V. (1991). Writing themes about literature. Prentice Hall.

Syahruddin, E., Herawaty, R., \& Ningrat, R. W. S. (2013). Effect of fermented katuk leaf (Sauropus androgynus L. Merr.) in diets on cholesterol content of broiler chicken carcass. Pakistan Journal of Nutrition, 12 (11), 1013. 